\section{'NuMex Crimson' Onion}

\section{Christopher S. Cramer ${ }^{1}$ and Joe N. Corgan ${ }^{2}$ \\ Department of Agronomy and Horticulture, Box 30003, MSC 3Q, New Mexico State University, Las Cruces, NM 88003-0003}

Additional index words. Allium cepa, Fusarium basal rot, Fusarium oxysporum f. sp. cepae, Phoma terrestris, pink root, vegetable breeding
The New Mexico State Univ. Agricultural Experiment Station announces the release of 'NuMex Crimson' onion (Allium cepa L.). 'NuMex Crimson' is an open-pollinated, early maturing, single centered, bolting resistant, moderately pink root tolerant, firm, flat globe, short-day, red-colored onion cultivar with excellent internal and external red scale color for fall seeding in southern New Mexico and similarenvironments, maturing in late May when fall seeded in Las Cruces, N.M.

\section{Origin} tercross in 1989 between 'Kurenai', 'Rojo', 'Red Grano', selections from a bolting resistant selections from 'Peckham Yellow Sweet Spanish', and selections from 'Henry's Special' crossed with 'Peckham Yellow Sweet Spanish'. 'Kurenai' is a short-day, red hybrid southern New Mexico. 'Kurenai' has uniform dark red to purple internal and external scale color. It is susceptible to pink root (Phoma terrestris) disease. 'Rojo' is a short-day, red southern New Mexico. It is an $\mathrm{F}_{1}$ hybrid developed and released by Arco Seed Co. in 1987 (Tigchelaar, 1991). 'Rojo' has uniform dark red to purple internal and external scale color. Bulbs are large, thick, and flat shaped. 'Rojo' is pink root resistant and closely resembles 'Red Granex'. 'Red Grano' is a short-day, open-pollinated red onion that matures early when fall-seeded in southern New Mexico. 'Red Grano' was developed by Dessert Seed Co. 'Texas Grano 502 PRR' is a pink-root-resistant selection from 'Texas Grano 502' (Corgan, 1984). 'Texas Grano 502' was selected from 'New Mexico Early Grano' that originated from lines introduced from Spain labeled as 'Valencia Grano' (Corgan, 1984; Garcia and Fite, 1931). 'Texas Early Grano 502 PRR' is a short-day, yellow onion that matures early when fall-planted in southern New Mexico. It is resistant to pink root when fall-planted. 'Texas Early Grano 502 PRR' is grano-shaped and produces large bulbs that are low in pungency and soluble solids, have soft flesh and

Received for publication 11 Mar. 2002. Accepted for publication 8 Aug. 2002. This research was funded by the NMSU Agricultural Experiment Station and the New Mexico Dry Onion Commission. solely to indicate this fact.

${ }^{1}$ Assistant Professor of Horticulture.

${ }^{2}$ Professor Emeritus and Jose Fernandez Chair of Crop Production.
'NuMex Crimson' originated from an inselection of 'Texas Early Grano 502 PRR', onion that matures early when fall-seeded in onion that matures early when fall-seeded in few dry scales, and store for short periods of time (Hawthorn, 1944). 'Texas Early Grano 502 PRR' has both normal $(\mathrm{N})$ and sterile (S) cytoplasm (Havey and Bark, 1994). 'Peckham Yellow Sweet Spanish' is a selection out of 'Yellow Sweet Spanish'. 'Peckham Yellow Sweet Spanish' is an intermediate-day, openpollinated yellow onion. It is susceptible to Fusarium basal rot (Fusarium oxysporum $\mathrm{f}$. sp. cepae) and pink root. It has a dark yellow outer dry scale. 'Yellow Sweet Spanish' was selected from 'Riverside Sweet Spanish' that was introduced from Spain in 1916. 'Henry's Special' is a short-day, yellow onion that is pink root resistant. It is an $\mathrm{F}_{1}$ hybrid developed and released by Arco Seed Co in 1965 (Tigchelaar, 1991). 'Henry's Special' is susceptible to cold injury when over-wintered in southern New Mexico. It has thin, dry outer scales and a top-shaped bulb.

The initial cross was made in 1989 by intercrossing the six parents in a common pollination cage, using honey bees as the pollen vector. Only seeds from the 'Kurenai' parent were collected and planted. Since 'Kurenai' is a hybrid, 'NuMex Crimson' likely possesses $\mathrm{S}$ cytoplasm. The following year, bulbs with excellent red scale color, bolting resistance, good root development, and a thick flat shape were selected using phenotypic evaluation. Selection was done at field maturity from fall seeding near Las Cruces, N.M. The selections were made from fields that contained high inoculum levels for Phoma terrestris (Hansen), causal organism of pink root, and Fusarium oxysporum $\mathrm{f}$. sp. cepae [(H.N. Hans.) W.C. Snyder \& H.N. Hans], causal organism of Fusarium basal rot. The selected bulbs were intercrossed and the resulting seed was planted in 1991. In 1992, 1994, 1996, 1998, and 2000, selections were made using phenotypic recurrent evaluation, and each year's selections were intercrossed to form the next generation following recurrent selection methods. For each selection, red bulbs that possessed early bulb maturity, uniform maturity, pink root resistance, bolting resistance, round bulb shape, uniform shape, hard bulb firmness, and excellent red internal and external scale color were selected. For the last two selections, bulbs were selected that possessed a single growing point or multiple growing points within $1.3 \mathrm{~cm}$ from the center of the bulb when cut transversely at the vertical middle of the bulb. These bulbs were advanced to the next cycle by planting the bottom half of the bulb. For the selections made in 1998, selections were made from both direct-seeded and transplanted plants.

Selection for bolting resistance was done from field plantings that possessed $70 \%$ or more plants with scapes at harvest time. Seed was planted around 1 Sept. to promote scape formation. This date is 3 to 4 weeks earlier than the earliest recommended planting date for fall-planted onions in southern New Mexico. Selection for pink root and Fusarium basal rot resistance was accomplished by planting selections in fields that were severely infested with $P$. terrestris, the causal organism of pink root and F. o.f. sp. cepae, the causal organism
Table 1. Performance of 'NuMex Crimson' and 'Cardinal' onions when grown on soil moderately infested with the pink root (Phoma terrestris) and the Fusarium basal rot (Fusarium oxysporum f. sp. cepae) pathogens at the Fabian Garcia Research Center, Las Cruces, N.M., from 1997 to 2001.

\begin{tabular}{|c|c|c|c|c|}
\hline Cultivar & $\begin{array}{l}\text { Marketable } \\
\text { yield }(\%)^{\mathrm{z}}\end{array}$ & $\begin{array}{l}\text { Marketable yield } \\
\left(\mathrm{t} \cdot \mathrm{ha}^{-1}\right)^{\mathrm{y}}\end{array}$ & $\begin{array}{l}\text { Avg bulb } \\
\text { wt }(g)^{x}\end{array}$ & $\begin{array}{c}\text { Single } \\
\text { centers }(\%)^{\mathrm{w}}\end{array}$ \\
\hline & \multicolumn{4}{|c|}{ 1997-98 (16 Sept. 1997 planting date) } \\
\hline Cardinal & 88 & 47.7 & 204 & --- \\
\hline \multirow[t]{3}{*}{ NuMex Crimson } & 90 & 50.6 & 201 & --- \\
\hline & NS & NS & NS & --- \\
\hline & \multicolumn{4}{|c|}{ 1998-99 (15 Sept. 1998 planting date) } \\
\hline Cardinal & 85 & 42.8 & 289 & 27.2 \\
\hline \multirow[t]{3}{*}{ NuMex Crimson } & 87 & 59.4 & 298 & 62.3 \\
\hline & NS & + & NS & $*$ \\
\hline & \multicolumn{4}{|c|}{ 1999-2000 (20 Sept. 1999 planting date) } \\
\hline Cardinal & 90 & 34.5 & 250 & 41.3 \\
\hline \multirow[t]{3}{*}{ NuMex Crimson } & 93 & 49.5 & 298 & 88.2 \\
\hline & NS & + & NS & $* *$ \\
\hline & \multicolumn{4}{|c|}{ 2000-01 (14 Sept. 2000 planting date) } \\
\hline Cardinal & 96 & 53.2 & 284 & 19.5 \\
\hline \multirow[t]{2}{*}{ NuMex Crimson } & 99 & 62.9 & 309 & 54.7 \\
\hline & NS & NS & NS & $* *$ \\
\hline
\end{tabular}

${ }^{\mathrm{z}}$ Percentage of marketable yield was calculated by dividing marketable bulb weight by total bulb weight. ${ }^{\mathrm{y}}$ Marketable bulb yield was calculated by weighing the marketable bulbs per plot and adjusting the plot size to 1 ha.

${ }^{\mathrm{x}}$ Average bulb weight was calculated by dividing the marketable bulb weight by the number of marketable bulbs.

${ }^{\mathrm{w}}$ The percentage of bulbs with single centers (single growing point) was determined by cutting each bulb transversely at the vertical center and measuring the number of growing points that extended $1.3 \mathrm{~cm}$ beyond the bulb's center.

Ns, $+,{ }^{*},{ }^{* *}$ Nonsignificant or significant at $P=0.10,0.05$, and 0.01 , respectively. Test was conducted at $\alpha=0.05$. 
for Fusarium basal rot. At bulb maturity, bulbs were rated for the incidence of pink root on their root system. Only bulbs that possessed a healthy root system with minimal symptoms of pink root were selected. At bulb maturity, bulbs possessing Fusarium basal rot were not selected. During storage, bulbs that developed Fusarium basal rot were discarded.

Selection for bulb shape was for a flat globe shape, and for a bulb that was more rounded, deeper than a typical thick, flat granex shape. Selection for bulb shape uniformity was for bulbs of the same size to possess the same desired shape. Selection for bulb scale color was based on the color of the dry outer and fleshy inner bulb scales. Selection for bulb or scale color was for a color that was comparable to 'Kurenai'. Selection for bulb shape and color was subjective, based on visual observation. Selection for bulb firmness was based on a subjective evaluation of the amount of bulb scale resistance when a force was applied to the bulb. Selection for bulb maturity was to select bulbs that matured the last week of May.

\section{Description and performance}

'NuMex Crimson' is an open-pollinated, early maturing, short-day, flat globe onion that matures from 24 to 29 May when fall seeded in Las Cruces, N.M. Suggested planting dates at Las Cruces are 15 Sept. to 1 Oct. 'NuMex Crimson' has excellent external and internal red scale color, excellent bolting resistance, a high percentage of single centered bulbs, moderate pink root tolerance, a flat globe shape, and firm bulbs.

Replicated field trials were conducted in 1997-98, 1998-99, 1999-2000, and 2000-01 comparing 'NuMex Crimson' to 'Cardinal', an $\mathrm{F}_{1}$ hybrid (Tables 1 and 2). 'Cardinal' is commonly grown commercially in New Mexico as a fall-seeded, short-day, overwintered, red onion for late May to early June maturity. 'NuMex Crimson' possessed a higher percentage of bulbs with single centers than 'Cardinal' (Table 1). In 2 years, 'NuMex Crimson' produced a higher marketable bulb yield than 'Cardinal' (Table 1). For percentage marketable yield and average bulb weight, 'NuMex Crimson' was comparable to 'Cardinal' (Table 1). For

Table 2. Performance of 'NuMex Crimson' and 'Cardinal' when grown on soil moderately infested with the pink root (Phoma terrestris) and the Fusarium basal rot (Fusarium oxysporum f. sp. cepae) pathogens at the Fabian Garcia Research Center, Las Cruces, N.M., from 1997 to 2001

\begin{tabular}{|c|c|c|c|c|c|c|}
\hline Cultivar & $\begin{array}{l}\text { Maturity } \\
\left(^{(D A S)^{z}}\right.\end{array}$ & $\begin{array}{c}\text { Scapes } \\
(\%)^{y}\end{array}$ & $\begin{array}{l}\text { Pink root } \\
\text { severity } \\
\text { rating }^{x}\end{array}$ & $\begin{array}{l}\text { Pink root } \\
\text { incidence } \\
(\%)^{\mathrm{w}}\end{array}$ & $\begin{array}{c}\text { Fusarium } \\
\text { basal rot } \\
\text { severity rating }^{\mathrm{v}}\end{array}$ & $\begin{array}{c}\text { Fusarium } \\
\text { basal rot } \\
\text { incidence }(\%)^{\mathrm{u}}\end{array}$ \\
\hline & \multicolumn{6}{|c|}{ 1997-98 (16 Sept. 1997 planting date) } \\
\hline Cardinal & 252 & 0.7 & 5.0 & --- & --- & --- \\
\hline \multirow[t]{3}{*}{ NuMex Crimson } & 251 & 2.2 & 4.1 & --- & --- & --- \\
\hline & NS & NS & NS & --- & --- & --- \\
\hline & \multicolumn{6}{|c|}{ 1998-99 (15 Sept. 1998 planting date) } \\
\hline Cardinal & 258 & 0.0 & 7.4 & --- & --- & --- \\
\hline \multirow[t]{3}{*}{ NuMex Crimson } & 251 & 0.0 & 4.5 & --- & --- & --- \\
\hline & NS & NS & $*$ & --- & --- & --- \\
\hline & \multicolumn{6}{|c|}{ 1999-2000 (20 Sept. 1999 planting date } \\
\hline Cardinal & 253 & 0.0 & 4.2 & 100 & 5.7 & 99 \\
\hline \multirow[t]{3}{*}{ NuMex Crimson } & 252 & 0.0 & 3.1 & 99 & 3.4 & 66 \\
\hline & NS & NS & NS & NS & $*$ & $*$ \\
\hline & \multicolumn{6}{|c|}{ 2000-01 (14 Sept. 2000 planting date) } \\
\hline Cardinal & 258 & 0.0 & 3.6 & 99 & 5.0 & 91 \\
\hline \multirow[t]{2}{*}{ NuMex Crimson } & 255 & 0.0 & 1.8 & 65 & 2.4 & 58 \\
\hline & NS & NS & + & $* *$ & $*$ & $*$ \\
\hline
\end{tabular}

${ }^{\mathrm{z}}$ An entry was harvested when all four replications had $80 \%$ of their tops down within the plot. A plot was considered matured when $80 \%$ of the tops were down. Days after seeding.

${ }^{y}$ The percentage of scapes was determined at harvest and calculated by dividing the number of plants with scapes by the total number of plants per plot.

${ }^{x}$ Root systems of 25 bulbs per plot were rated based on a scale of 1 (no infected roots) to 9 (completely infected roots).

${ }^{\text {w }}$ Percentage of bulbs with pink root.

${ }^{v}$ Cut basal plates of 25 bulbs per plot were rated based on a scale of 1 (no disease tissue) to 9 (70\% or more of basal plate decayed).

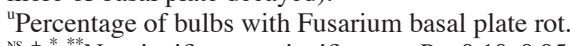

Ns,,$* * * * *$ Nonsignificant or significant at $P=0.10,0.05$, and 0.01 , respectively. Test was conducted at $\alpha=0.05$.

2 years, 'NuMex Crimson' had a lower pink root severity rating than 'Cardinal' (Table 2). In 2000, 'NuMex Crimson' had a lower pink root incidence (percentage of bulbs exhibiting pink root symptoms) than 'Cardinal' (Table 2). For the two years measured, 'NuMex Crimson' had a lower Fusarium basal rot severity rating and incidence than 'Cardinal' (Table 2). 'NuMex Crimson' and 'Cardinal' were similar in maturity date and lack of seedstalk formation (Table 2).

\section{Availability}

Currently, 'NuMex Crimson' is being produced, marketed, and sold exclusively by Lockhart Seed Co., Inc., Stockton, Calif. Application for Plant Variety Protection has been filed.

\section{Literature Cited}

Corgan, J.N. 1984. 'NuMex BR 1' onion. HortScience 19:593.

Garcia, F. and A.B. Fite. 1931. Early grano onion culture. N.M. Agr. Expt. Sta. Bul. 193.

Havey, M.J. and O. H. Bark. 1994. Molecular confirmation that sterile cytoplasm has been introduced into open-pollinated grano onion cultivars. J. Amer. Soc. Hort. Sci. 119:90-93.

Hawthorn, L.R. 1944. Texas grano onion. Texas Agr. Expt. Sta. Prog. Rpt. 899.

Tigchelaar, E.C. 1991. New vegetable variety list 23. HortScience 26:343-357. 